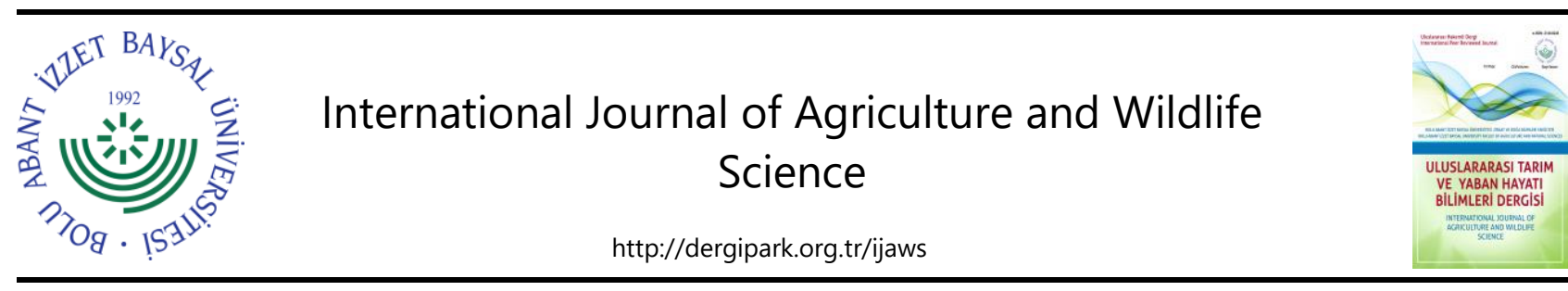

Research Article

\title{
The Effects of Stocking Density on Some Meat Quality Parameters and Taste of Meat Turkeys
}

\author{
Sabri Arda Eratalar ${ }^{1 *}, \quad$ Rüveyde Akbay ${ }^{2}$ \\ 1Department of Poultry Science, Faculty of Agriculture and Natural Sciences, Abant İzzet Baysal University, Bolu, Turkey \\ ${ }^{2}$ Department of Animal Science, Faculty of Agriculture, Ankara University, Ankara, Turkey
}

Received: 07.09.2018 Accepted: 21.12.2018

\section{Keywords:}

Turkey, stocking density, meat quality, meat taste, panel

*Corresponding author ardaeratalar@ibu.edu.tr

Abstract. One of the most important factors in turkey meat production is the effects of stocking density on meat quality as it is a favored source of animal protein consumed in the world as it is in our country. This issue, may have important effects on meat quality, is also regarded as a parameter that can make a difference in terms of meat flavor. In the study, the subject was worked on both sides. In the study, Hybrid Converter white meat turkey poults were used after numbering right after hatch. The study was carried out on 200 turkeys with 30, 40, 50 and $60 \mathrm{~kg}$ live weights per square meter, with 25 different poults per pen, separated by male and female in different sized pens. The study was carried out for 16 weeks in females and 20 weeks in males. The slaughtering was carried out under Islamic conditions and the necessary data were obtained from the animals to determine the parameters related to meat quality. Findings obtained from the study were subjected to statistical analysis and the effects of meat quality and taste on the meat of these animals were evaluated in terms of general stocking density applications in our country and the results were evaluated. Despite the fact that the meat quality was not seriously affected in terms of stocking density, better results were obtained in terms of appearance of meat in thigh and generally in breast meat of females with decreasing stocking density.
\end{abstract}

\section{Etlik Hindilerde Yerleşim Sıklığının Bazı Et Kalite Parametrelerine ve Et Lezzetine Etkileri}

\begin{tabular}{|c|c|}
\hline Anahtar kelimeler: & Özet. Dünyada da ülkemizde olduğu gibi sevilerek tüketilen hayvansal protein kaynağı olan hindi \\
\hline $\begin{array}{l}\text { Hindi, yerleşim sıklığı, et } \\
\text { kalitesi, et lezzeti, panel }\end{array}$ & $\begin{array}{l}\text { etinin üretimi bakımından önemli olan bir husus da yerleşim sıklığıdır. Et kalitesi bakımından önemli } \\
\text { etkileri olabilecek olan bu konu aynı zamanda et lezzeti açısından da fark oluşturabilecek bir } \\
\text { parametre olarak değerlendirilmektedir. Çalışmada, konu her iki açıdan da çalışılmıştır. Çalışmada } \\
\text { melez ticari etlik hindi hatlarından Hybrid Converter beyaz etlik hindi palazları, yumurtadan çıkışı } \\
\text { takiben numaralandırılarak kullanılmıştır. Çalışma } 200 \text { hindi palazı, kesim yaşında metrekareye } 30,40 \text {, } \\
50 \text { ve } 60 \text { kg canlı ağırlık gelecek şekilde farkıı ebatlarda yapılmış bölmelere erkek ve dişi ayrı olmak } \\
\text { üzere, } 25 \text { 'er adet palaz konacak şekilde yerleştirilmiştir. Çalışma dişilerde } 16 \text { hafta, erkeklerde } 20 \\
\text { hafta sürdürülmüş olup, kesim işlemleri İslami koşullarda gerçekleştirilmiş olup kesilen hayvanlardan } \\
\text { et kalitesi ile ilgili parametrelerin tespiti için gerekli veriler alınmıştır. Çalışmadan elde edilen bulgular } \\
\text { istatistik analize tabi tutularak ülkemizdeki genel yerleşim sılığı uygulamaları bakımından } \\
\text { hayvanların et kalitesi ve lezzetine etkileri incelenerek sonuçları değerlendirilmiştir. Hindilerde et } \\
\text { kalitesinin ciddi şekilde etkilenmemiş olmasına rağmen yerleşim sıklığının artışına bağlı olarak et } \\
\text { görünüşü bakımından erkeklerde fark olmamakla birlikte, dişilerde but etinde görsel, göğüs etinde } \\
\text { de genel olarak yerleşim sıklığı düşük gruplarda daha iyi sonuçlar elde edilmiştir. }\end{array}$ \\
\hline
\end{tabular}




\section{INTRODUCTION}

As being an important animal protein source, turkey meat production is also an important branch in the world poultry meat industry as it is in Turkey. Where the population grows in Turkey and also the world, animal protein need increases more than the increase in overall production. Turkey's population has increased where turkey meat production increased only Mton. This shows an increase in production gap for need of animal protein coming from turkey meat in the world as it is in Turkey, can clearly be seen on figure 1 (FAO, 2015; TUIK, 2016).

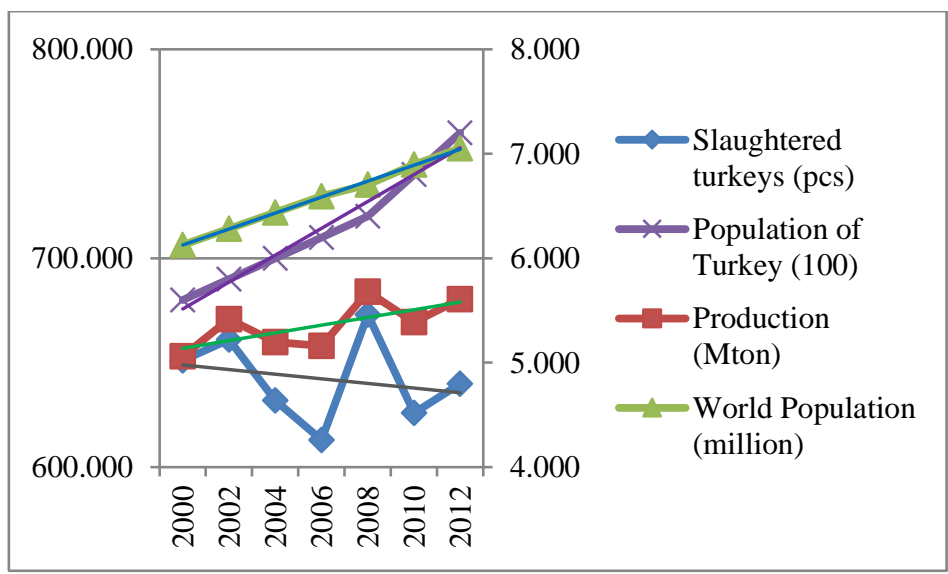

Figure 1. Turkey, World Population and turkey meat production from 2000 to 2012 (FAO, 2015; TUIK, 2016).

Şekil 1. 2000 - 2012 yılları arasında Türkiye'de ve dünyada hindi eti üretim miktarları.

Being a nutritive and precious source of animal protein, the properties of turkey meat can be seen on Figure 2. With a delicious unique aroma and taste, its protein level is similar to the one in cattle but also less in fat. This makes turkey meat a better option for people on a diet (Eratalar and Bulut 2007) as seen on Table 1.

Table 1. Nutritional value of $100 \mathrm{~g}$ meat from different farm animals (Ertugrul, 1997, Ergün et al., 2001).

Çizelge 1. Faklı çiftlik hayvanlarına ait 100 gram etin besin değeri.

\begin{tabular}{lllll}
\hline & Broiler & Turkey & Cattle & Lamb \\
\hline Energy kcal/kg & 215 & 160 & 194 & 228 \\
Protein g & 18.60 & 20.40 & 20.00 & 14.00 \\
Fat g & 15.10 & 8.00 & 12.00 & 18.00 \\
\hline
\end{tabular}

In Turkey, public request is mostly thigh and wing meat of poultry where European countries and United States mostly demand on breast meat providing the country to sell wings and legs in the country and export breast meat to Europe for better profits.

The genetic potential for growth and meat yield of turkeys can only be seen under the best environmental conditions. Stocking density is considered to be one of the most important primary factors affecting the birds' performance and meat production.

In a research, Noll et al. (1991) set 2.20 and 4.80 male turkeys per square meters. Researchers arrived at the data that the birds at higher stocking density had less live weight than the others. As well, a supporting research result comes from Dogrul et al. (2005). Researchers have designed a work with 3 and 4 birds $\mathrm{m}^{-2}$ and concluded that birds reared at higher stocking density (SD) resulted in worse growth performance.

Proudfoot et al. (1985) reported that with increasing stocking density slaughter weight decreases and skin lesions increased. Also in Label Rouge free range chickens Farmer et al. (1997) reported that unwanted smells were higher in the meat of the birds reared under lower stocking densities reporting that the difference may not be arising from stocking density but age of the birds.

Barbut (1998) has reported that the most important criterion for meat color is the $L$ value itself.

Mirabito et al. (2002) reported that there has been found no difference between the meat of the different stocking density groups in terms of breast blisters, carcass deformation, injuries and total meat quality with SDs of 7 and 8.50 birds $\mathrm{m}^{-2}$.

With a different production system of different cage stocking densities $0.23,0.30$ and $0.56 \mathrm{~m}^{-2} \mathrm{~s}$ there has been found no difference between the treatment groups in terms of meat quality parameters. 
Riegel et al. (2004) has reported that as a meat quality parameter $\mathrm{pH}$ of the birds were found to be around $6.50 \pm 0.05$, color parameter $L$ were found to be around $16.40 \pm 1.00$, breast protein was found to be around $25.00 \pm 0.10 \%$, breast fat was found to be around $0.40 \pm 0.91 \%$ and dry matter was found to be around $15.90 \pm 0.10 \%$.

Santos et al. (2004) reported that the thigh meat yield was found to be higher in males than the females where the breast meat yield was reported to be higher in females than males.

Thomas et al. (2004) reported that there has been found no significant difference between the treatment groups of chickens reared under different SDs.

Doğrul et al. (2005) reported that the turkey poults reared under lower stocking densities had higher carcass weight than the ones reared under higher SDs.

Molette et al. (2005) reported that the cold pH (24 hours) values of turkeys were found to be around $5.67 \pm 0.06$, $L$ values were found to be around $52.43 \pm 3.24$, a values were found to be around $4.77 \pm 1.02$ and $b$ values were found to be around 2.23.

Peryam et al. (1957) reported that the taste of meat can be scored from 1 to 9 with a hedonic scale and constructed the first meat scoring technique by which the panel was also based on in the experiment.

Poste (1990) has reported that the job should be properly explained to the panelists who will taste the meat before the procedure begins. In the experiment the method was explained with detail before the panel started as it was briefed by the researcher.

Turhan (1992) has constructed an experimented on chickens including a tasting panel and cooked the chicken meat, breast and thigh separately for 50 minutes in steel cookers. The samples were given to the panelists with bread and water to eliminate the former taste of the samples.

Gatchalian (1999) reported that the treated parameters should be smell, taste, structure, look and softness. $\mathrm{Xu}(1999)$ has also reported that in panels there should be more than 100 amateur panelists or more than 3 professional panelists to get better results from panel experiments.

Reilly et al. (2001) also explained the environment for a better panel to achieve best results from tasting panel experiments as this experiment was also conducted in the direction of these reports.

As seen there have been several experiments about SD for chickens and turkeys. However, there is no similarity of these researches with our experiment in terms of degustation (tasting) panel, meat quality parameters etc. This research is important for introducing the present condition for determining the stocking density effect on meat quality levels and taste of meat of these turkeys in the aspect of turkey production in Turkey.

\section{MATERIAL AND METHOD}

The turkey poults forming the animal material of this research was obtained from a private turkey meat production company integration founded in Bolu, located in the northern part Turkey. The hatching eggs which the poults hatched from were obtained from 42 week old Hybrid Converter breeders reared in the same breeder house. 200 hatching eggs of these breeders were hatched in the company's hatchery and were transferred to the production farm of the company immediately prior to automatic vaccination, sexing and beak trimming which were done at the hatchery right after hatch. The birds were randomly wing-banded, numbered from 1 to 200. So, all the birds would be personally tested as a replicate for the related parameters investigated.

Research took place in commercial company's turkey farm and cages were built in before the research was set. Female cages were $8.245 \mathrm{~m}^{2}, 6.179 \mathrm{~m}^{2}, 4.943 \mathrm{~m}^{2}$ and $4.125 \mathrm{~m}^{2}$ for $30,40,50$ and $60 \mathrm{~kg} \mathrm{~m}^{-2}$ estimated live weight at the slaughter age of the birds at $16^{\text {th }}$ week of rearing period. Male cages were $15.443 \mathrm{~m}^{2}, 11.575 \mathrm{~m}^{2}$, $9.363 \mathrm{~m}^{2}$ and $7.727 \mathrm{~m}^{2}$ for $30,40,50$ and $60 \mathrm{~kg} \mathrm{~m}^{-2}$ estimated slaughter weight of the poults at $20^{\text {th }}$ week of rearing period.

Birds were placed in 8 pens 4 male pens and 4 female pens with 25 birds in each pen. In the first 2 weeks birds were reared in rings for better start and the rings were removed at the $2^{\text {nd }}$ week. So, the SD (stocking density) effect was put on in the $2^{\text {nd }}$ week. The SD levels were arranged for the birds' estimated slaughter weights of 30, 40, 50 and $60 \mathrm{~kg} \mathrm{~m}^{-2}$.

The slaughter weights (SW) of the birds came up higher but not more than $2.5 \%$ than the estimated SW set at the beginning of the study.

Vaccination program for the birds used by the company is shown at Table 2. 
Table 2. The vaccination program used in the experiment. Çizelge 2. Denemede kullanllan aşılama programı.

\begin{tabular}{lllll}
\hline Time & Vaccine & Type & Method & The Disease \\
\hline After hatch & HB1 & Active & Spray & Newcastle D. \\
7. Day & TRT & Active & Spray & TRT \\
21. Day & Clone 30 & Active & Spray & Newcastle D. \\
35. Day & TRT & Active & Spray & TRT \\
56. Day & Lasota & Active & Spray & Newcastle D. \\
\hline
\end{tabular}

Male birds were fed with 8 different types of feed where females were fed with 7 different feed in the rearing period. Males were slaughtered at the $20^{\text {th }}$ week where females were at $16^{\text {th }}$ week which were the suitable and the present application at the time of the study. This rearing period is as well up to date and used by the industry still (Housmand et al., 2012; Qaid et al., 2016).

Feed and water were given ad-libitum. All the feed were obtained from Bolca Hindi's feed mill. The chemical and physical composition of the feed is shown in Table 3.

Table 3. Feeds' chemical and physical contents for the rearing period.

Çizelge 3. Yetiştirme dönemi boyunca kullanılan yemin fiziksel ve kimyasal özellikleri.

\begin{tabular}{lllllllll}
\hline Feed No & $\mathbf{3 0 1}$ & $\mathbf{3 0 2}$ & $\mathbf{3 0 3}$ & $\mathbf{3 0 4}$ & $\mathbf{3 0 5}$ & $\mathbf{3 0 6}$ & $\mathbf{3 0 7}$ & $\mathbf{3 0 8}$ \\
\hline Weeks & $0-2$ & $2-4$ & $4-6$ & $7-9$ & $10-12$ & $13-14$ & $15-16$ & $17+$ \\
Crude Protein (\%) & 28.50 & 27.50 & 26.00 & 23.50 & 21.50 & 19.50 & 18.00 & 17.00 \\
ME (Kcal kg-1) & 2750 & 2850 & 2950 & 3050 & 3125 & 3225 & 3350 & 3400 \\
Methionine & 0.74 & 0.69 & 0.63 & 0.56 & 0.50 & 0.44 & 0.40 & 0.37 \\
Meth. + Syst. & 1.21 & 1.17 & 1.07 & 1.00 & 0.90 & 0.80 & 0.72 & 0.68 \\
Lysine & 1.85 & 1.8 & 1.66 & 1.55 & 1.40 & 1.20 & 1.02 & 0.90 \\
Calcium & 1.45 & 1.40 & 1.40 & 1.30 & 1.20 & 1.10 & 1.00 & 1.00 \\
Digestible Phosphorus & 0.78 & 0.75 & 0.75 & 0.65 & 0.60 & 0.55 & 0.50 & 0.50 \\
Sodium & 0.17 & 0.17 & 0.17 & 0.18 & 0.18 & 0.18 & 0.18 & 0.18 \\
Threonine & 1.11 & 1.10 & 1.04 & 1.00 & 0.93 & 0.76 & 0.64 & 0.58 \\
Tryptophan & 0.34 & 0.30 & 0.27 & 0.25 & 0.23 & 0.20 & 0.18 & 0.17 \\
Arginine & 1.98 & 1.94 & 1.79 & 1.63 & 1.44 & 1.24 & 1.05 & 0.93 \\
Structure of the Feed & Crumble & Pellet & Pellet & Pellet & Pellet & Pellet & Pellet & Pellet \\
\hline
\end{tabular}

Lighting program was the same for all the birds with a beginning of 100 lux florescent light at bird level and after $2^{\text {nd }}$ day dark period began with 30 minutes and increased 30 minutes every day up to 6 hours of dark and 18 hours of light which was continued till the end of the rearing period. 100 lux was decreased to 75 lux at day 7 and it was decreased to 50 lux at the $2^{\text {nd }}$ week and went on till slaughter age.

The poults arrived at the farm were reared at $37.00 \pm 0.50^{\circ} \mathrm{C}$ and the temperature was decreased $0.50{ }^{\circ} \mathrm{C}$ daily till the rearing environment is finally $20.00^{\circ} \mathrm{C}$ and this temperature $\left(20.00 \pm 0.50^{\circ} \mathrm{C}\right)$ was kept till the slaughter age.

Proper ventilation was obtained by an automatic environment control system controlling the side curtains during the whole period of the study.

Health control was done by the company's veterinarian where no drugs and feed additives were used during the whole study.

Dry pinewood shavings were used as the litter material which was disinfected and spread about $5 \mathrm{~kg} \mathrm{~m}^{-2}$ to the ground homogeneously.

The data achieved were analyzed with Minitab 14 statistical analysis software program using variance analysis and Duncan Test (Düzgüneş et al., 1987; Sheskin, 2000; Minitab, 2014).

All samples were analyzed separately by a linear model as shown below.

$Y_{i j}=\mu+\alpha_{i}+e_{i j}$

$\mathrm{Y}_{\mathrm{ij}} \quad: \quad \mathrm{i}^{\text {th }}$ stocking density group, $\mathrm{j}^{\text {th }}$ week observed value

$\mu \quad$ : $\quad$ population mean for the parameter

$\alpha_{i} \quad: \quad i^{\text {th }}$ stocking density group effect

$e_{i j} \quad: \quad$ random error 


\section{RESULTS AND DISCUSSION}

From the data of the experiment it was found that there has been no statistically significant $(P>0.05)$ change between the treatment groups in terms of slaughter weight, hot and cold carcass weights and, hot and cold carcass yield data as seen in Table 4. The data is not in line with other researchers conducted by Proudfoot et al. (1985), Dogrul et al. (2005), Azzam and Gogary (2015) and Noll et al. (1991) where live weight and slaughter weight of turkeys were reported to be decreasing with increased SDs. This may be arising because these researchers used more compelling SD levels than used in our trial.

Table 4. Carcass weight and carcass yield of male and female turkeys reared under different SDs.

Çizelge 4. Farklı yerleşim sıklıklarında yetiştirilen erkek ve diş̧ hindilerde karkas ağırlı̆̆ ve randımanı.

\begin{tabular}{|c|c|c|c|c|c|c|}
\hline \multirow[b]{2}{*}{ Sex } & \multirow{2}{*}{$\begin{array}{l}\text { Stocking } \\
\text { density } \\
\left(\mathrm{kg} \mathrm{m}^{-2}\right)\end{array}$} & \multicolumn{3}{|c|}{ Carcass weight $(g)(\bar{x} \pm S \bar{x})$} & \multicolumn{2}{|l|}{ Carcass yield (\%) } \\
\hline & & $\begin{array}{l}\text { Slaughter } \\
\text { weight }\end{array}$ & $\begin{array}{l}\text { Hot carcass } \\
\text { weight }\end{array}$ & $\begin{array}{l}\text { Cold } \\
\text { weight }\end{array}$ & $\begin{array}{l}\text { Hot carcass } \\
\text { yield }\end{array}$ & carcass \\
\hline \multirow{7}{*}{ Males } & 60 & $19620 \pm 136.56$ & $15370 \pm 169.46$ & $15100 \pm 157.32$ & $78.36 \pm 1.22$ & $76.98 \pm 1.14$ \\
\hline & 50 & $19220 \pm 563.26$ & $15308 \pm 570.99$ & $15023 \pm 577.50$ & $79.57 \pm 0.64$ & $78.07 \pm 0.73$ \\
\hline & 40 & $19390 \pm 288.70$ & $15087 \pm 460.77$ & $14832 \pm 449.85$ & $77.75 \pm 1.55$ & $76.44 \pm 1.51$ \\
\hline & 30 & $19840 \pm 404.78$ & $15314 \pm 229.04$ & $14963 \pm 203.33$ & $77.23 \pm 0.89$ & $75.47 \pm 0.86$ \\
\hline & $\mathrm{S} \overline{\mathrm{x}}$ & 183.21 & 182.27 & 179.41 & 0.55 & 0.55 \\
\hline & $\mathrm{F}$ & 0.501 & 0.101 & 0.085 & 0.791 & 0.961 \\
\hline & $\mathrm{P}$ & $>0.05$ & $>0.05$ & $>0.05$ & $>0.05$ & $>0.05$ \\
\hline & 60 & $10949 \pm 370.26$ & $8800 \pm 398.31$ & $8386 \pm 259.28$ & $80.36 \pm 2.41$ & $76.63 \pm 0.74$ \\
\hline & 50 & $10158 \pm 341.70$ & $8014 \pm 290.26$ & $7902 \pm 291.23$ & $78.87 \pm 0.78$ & $77.77 \pm 0.83$ \\
\hline & 40 & $10684 \pm 560.37$ & $8622 \pm 273.52$ & $8485 \pm 267.30$ & $81.32 \pm 3.75$ & $80.04 \pm 3.73$ \\
\hline \multirow[t]{4}{*}{ Females } & 30 & $9768 \pm 740.41$ & $8264 \pm 458.66$ & $8126 \pm 455.00$ & $85.41 \pm 3.69$ & $83.98 \pm 3.63$ \\
\hline & $\mathrm{S}_{\overline{\mathrm{x}}}$ & 264.16 & 180.88 & 159.34 & 1.45 & 1.38 \\
\hline & $\mathrm{F}$ & 1.003 & 0.945 & 0.643 & 0.918 & 1.480 \\
\hline & $\mathrm{P}$ & $>0.05$ & $>0.05$ & $>0.05$ & $>0.05$ & $>0.05$ \\
\hline
\end{tabular}

Hot and cold carcass $\mathrm{pH}$ values were found to be stable and unchanging $(P<0.05)$ between the treatment groups which are in line with other research reporting that different SDs not affecting meat quality by Mirabito et al. (2002) and Rieger et al. (2004) also reporting that $\mathrm{pH}$ values were found to be around 6.50 which seems to be higher than the values obtained from our experiment may be resulting because of the different ages of the slaughtered birds. Results reported of a research conducted by Molette et al. (2005) are around 5.67 which are also very parallel to the research data also reporting similarly as there has been no change in $\mathrm{pH}$ as the SD increased. WHC of turkeys reared under different SDs were found to be unaffected by SDs of $30-60 \mathrm{~kg} \mathrm{~m}^{-2}$ in our experiment as can be seen in Table 5.

Table 5. Hot and cold carcass pH and, WHC values of male and female turkeys reared under different SDs.

Çizelge 5. Farklı yerleşim sıklıklarında yetiştirilen erkek ve dişi hindilerde sıcak ve soğuk karkas pH'sı ve STK değerleri.

\begin{tabular}{|c|c|c|c|c|c|c|c|c|}
\hline $\begin{array}{l}\text { Stocking } \\
\text { Density }\end{array}$ & Males & & Females & & Males & & Females & \\
\hline$\left(\mathrm{kg} \mathrm{m}^{-2}\right)$ & $\begin{array}{l}\text { Hot } \\
\text { Carcass pH }\end{array}$ & $\begin{array}{l}\text { Cold } \\
\text { Carcass pH }\end{array}$ & $\begin{array}{l}\text { Hot Carcass } \\
\text { pH }\end{array}$ & $\begin{array}{l}\text { Cold Carcass } \\
\text { pH }\end{array}$ & Thigh WHC & Breast WHC & $\begin{array}{l}\text { Thigh } \\
\text { WHC }\end{array}$ & $\begin{array}{l}\text { Breast } \\
\text { WHC }\end{array}$ \\
\hline 60 & $5.79 \pm 0.07$ & $5.69 \pm 0.02$ & $5.27 \pm 0.06$ & $5.49 \pm 0.03$ & $48.02 \pm 1.33$ & $52.86 \pm 4.50$ & $37.97 \pm 2.02$ & $58.09 \pm 4.79$ \\
\hline 50 & $5.88 \pm 0.09$ & $5.73 \pm 0.01$ & $5.28 \pm 0.08$ & $5.50 \pm 0.04$ & $53.47 \pm 1.70$ & $56.03 \pm 4.43$ & $33.75 \pm 1.27$ & $52.24 \pm 1.12$ \\
\hline 40 & $5.84 \pm 0.07$ & $5.71 \pm 0.02$ & $5.32 \pm 0.09$ & $5.46 \pm 0.04$ & $46.63 \pm 1.43$ & $53.70 \pm 2.28$ & $43.88 \pm 2.10$ & $55.48 \pm 1.54$ \\
\hline 30 & $6.03 \pm 0.06$ & $5.68 \pm 0.03$ & $5.40 \pm 0.05$ & $5.57 \pm 0.03$ & $59.44 \pm 2.67$ & $52.82 \pm 1.89$ & $38.22 \pm 4.08$ & $54.10 \pm 1.61$ \\
\hline Sx & 0.04 & 0.01 & 0.03 & 0.02 & 1.04 & 1.62 & 1.44 & 1.33 \\
\hline $\mathrm{F}$ & 1.759 & 0.838 & 0.490 & 1.409 & 2.588 & 0.186 & 2.571 & 0.829 \\
\hline$P$ & $>0.05$ & $>0.05$ & $>0.05$ & $>0.05$ & $>0.05$ & $>0.05$ & $>0.05$ & $>0.05$ \\
\hline
\end{tabular}


As the chemical properties of turkeys reared under different SDs were analyzed, no significant $(P>0.05)$ differences between treatment groups were found except the protein ingredient of female turkeys $(P<0.05)$ reared under highest SD which was found to have the highest protein level as well. The data of protein and fat values are in line with other research conducted by Rieger et al. (2004). The data obtained from the research can be seen in Table 6.

Table 6. Some chemical properties of male and female turkeys reared under different SDs.

Çizelge 6. Farklı yerleşim sıklıklarında yetiştirilen erkek ve dişi hindilerde bazı kimyasal özellikler.

\begin{tabular}{|c|c|c|c|c|c|c|c|}
\hline \multirow[b]{2}{*}{ Sex } & \multirow{2}{*}{$\begin{array}{l}\text { Stocking } \\
\text { density } \\
\left(\mathrm{kg} \mathrm{m}^{-2}\right)\end{array}$} & \multicolumn{3}{|c|}{ Thigh meat chemical properties $(\overline{\mathrm{X}} \pm \mathrm{S} \overline{\mathrm{x}})$} & \multicolumn{3}{|c|}{ Breast meat chemical properties $(\overline{\mathrm{X}} \pm S \overline{\mathrm{x}})$} \\
\hline & & Protein (\%) & Fat (\%) & Dry Matter (\%) & Protein (\%) & Fat (\%) & Dry matter (\%) \\
\hline \multirow{7}{*}{ Males } & 60 & $20.78 \pm .034$ & $3.88 \pm 0.55$ & $24.83 \pm 0.37$ & $23.49 \pm 0.10$ & $0.88 \pm 0.04$ & $24.96 \pm 0.58$ \\
\hline & 50 & $21.00 \pm 0.32$ & $3.24 \pm 1.04$ & $23.80 \pm 0.57$ & $23.78 \pm 0.40$ & $1.36 \pm 0.37$ & $25.03 \pm 0.32$ \\
\hline & 40 & $19.85 \pm 0.37$ & $4.21 \pm 1.53$ & $24.50 \pm 0.89$ & $23.66 \pm 0.23$ & $0.77 \pm 0.14$ & $24.13 \pm 0.27$ \\
\hline & 30 & $20.10 \pm 0.36$ & $3.35 \pm 0.34$ & $33.43 \pm 1.20$ & $24.26 \pm 0.28$ & $0.77 \pm 0.30$ & $25.20 \pm 0.26$ \\
\hline & $\mathrm{S}_{\bar{x}}$ & 0.20 & 0.43 & 0.29 & 0.14 & 0.12 & 0.20 \\
\hline & $\mathrm{F}$ & 2.377 & 0.215 & 1.264 & 1.418 & 1.240 & 1.559 \\
\hline & $\mathrm{P}$ & $>0.05$ & $>0.05$ & $>0.05$ & $>0.05$ & $>0.05$ & $>0.05$ \\
\hline \multirow{7}{*}{ Females } & 60 & $19.98 \pm 0.50$ & $8.70 \pm 0.50$ & $31.13 \pm 0.73 a$ & $26.26 \pm 0.38 \mathrm{a}$ & $0.96 \pm 0.48$ & $26.80 \pm 0.50$ \\
\hline & 50 & $20.84 \pm 0.39$ & $7.23 \pm 2.42$ & $29.60 \pm 0.30 a b$ & $24.72 \pm 0.26 \mathrm{~b}$ & $1.16 \pm 0.04$ & $25.93 \pm 0.12$ \\
\hline & 40 & $20.56 \pm 0.07$ & $8.66 \pm 1.70$ & $29.53 \pm 1.18 a b$ & $25.54 \pm 0.36 \mathrm{ab}$ & $0.83 \pm 0.18$ & $27.10 \pm 0.35$ \\
\hline & 30 & $20.15 \pm 0.04$ & $7.26 \pm 0.76$ & $27.63 \pm 0.78 b$ & $25.53 \pm 0.05 a b$ & $0.49 \pm 0.20$ & $27.26 \pm 0.81$ \\
\hline & $S_{\bar{x}}$ & 0.17 & 0.69 & 0.51 & 0.20 & 0.13 & 0.26 \\
\hline & $\mathrm{F}$ & 1.434 & 0.285 & 3.092 & 4.423 & 1.005 & 1.330 \\
\hline & $\mathrm{P}$ & $>0.05$ & $>0.05$ & $>0.05$ & $<0.05$ & $>0.05$ & $>0.05$ \\
\hline
\end{tabular}

The statistically different data is shown with small characters and $P$ values are as given.

As the color properties' data were investigated, it was found that there were no significant $(P>0.05)$ differences between treatment groups of the experiment. These findings are close to other researches' results done by Molette et al. (2005).

Table 7. Color properties of male and female turkeys reared under different SDs.

Çizelge 7. Farklı yerleşim sıklıklarında yetiştirilen erkek ve dişi hindilerde renk özellikleri.

\begin{tabular}{|c|c|c|c|c|c|c|c|}
\hline \multirow[b]{2}{*}{ Sex } & \multirow{2}{*}{$\begin{array}{l}\text { Stocking } \\
\text { density } \\
\left(\mathrm{kg} \mathrm{m}^{-2}\right)\end{array}$} & \multicolumn{3}{|c|}{ Thigh meat color $(\bar{x} \pm S \bar{x})$} & \multicolumn{3}{|c|}{ Breast meat color $(\overline{\mathrm{X}} \pm \mathrm{S} \overline{\mathrm{x}})$} \\
\hline & & $\mathbf{L}$ & a & b & $\mathbf{L}$ & $\mathbf{a}$ & b \\
\hline \multirow{7}{*}{ Males } & 60 & $40.95 \pm 2.50$ & $11.28 \pm 0.33$ & $11.28 \pm 0.33$ & $41.03 \pm 1.18$ & $10.87 \pm 1.48$ & $5.47 \pm 0.65$ \\
\hline & 50 & $38.21 \pm 1.22$ & $12.81 \pm 0.72$ & $12.81 \pm 0.72$ & $43.15 \pm 1.24$ & $10.35 \pm 1.22$ & $5.42 \pm 0.62$ \\
\hline & 40 & $40.87 \pm 2.01$ & $12.08 \pm 0.59$ & $12.08 \pm 0.59$ & $43.40 \pm 1.01$ & $13.47 \pm 0.92$ & $6.22 \pm 0.37$ \\
\hline & 30 & $40.27 \pm 1.07$ & $12.16 \pm 0.46$ & $12.16 \pm 0.46$ & $39.92 \pm 1.30$ & $10.89 \pm 1.73$ & $6.05 \pm 0.22$ \\
\hline & $S_{\bar{x}}$ & 0.86 & 0.28 & 0.28 & 0.64 & 0.68 & 0.24 \\
\hline & $\mathrm{F}$ & 0.503 & 1.303 & 0.808 & 1.987 & 1.043 & 0.659 \\
\hline & $\mathrm{P}$ & $>0.05$ & $>0.05$ & $>0.05$ & $>0.05$ & $>0.05$ & $>0.05$ \\
\hline \multirow{7}{*}{ Females } & 60 & $48.57 \pm 0.90$ & $7.93 \pm 0.57$ & $6.92 \pm 0.53$ & $45.54 \pm 1.34$ & $7.05 \pm 1.47$ & $5.95 \pm 0.20 b$ \\
\hline & 50 & $47.11 \pm 1.23$ & $7.66 \pm 0.25$ & $6.12 \pm 0.40$ & $46.93 \pm 0.70$ & $7.90 \pm 1.60$ & $6.30 \pm 0.59 a b$ \\
\hline & 40 & $47.71 \pm 0.70$ & $7.76 \pm 0.57$ & $6.67 \pm 0.36$ & $45.55 \pm 0.76$ & $5.85 \pm 0.30$ & $6.99 \pm 0.35 \mathrm{ab}$ \\
\hline & 30 & $46.87 \pm 0.78$ & $7.87 \pm 0.71$ & $6.54 \pm 0.11$ & $45.00 \pm 1.19$ & $9.96 \pm 1.42$ & $7.25 \pm 0.24 \mathrm{a}$ \\
\hline & $S_{\bar{x}}$ & 0.45 & 0.25 & 0.19 & 0.50 & 0.69 & 0.21 \\
\hline & $\mathrm{F}$ & 0.668 & 0.048 & 0.744 & 0.629 & 1.741 & 2.496 \\
\hline & $\mathrm{P}$ & $>0.05$ & $>0.05$ & $>0.05$ & $>0.05$ & $>0.05$ & $<0.05$ \\
\hline
\end{tabular}

The statistically different data is shown with small characters and $P$ values are as given.

When organoleptic parameters investigated in the trial were analyzed, it can be told that in general the scores are getting better visually as SD decreases but these differences were found to be insignificant $(P>0.05)$. Only visual scores of female thigh meats and general scores of female breast meats were found to be increasing with decreasing SD significant statistically $(P<0.05)$. The data of the experiment can be seen in Table 8 . 
Table 8. Organoleptic properties of male and female turkeys reared under different SDs.

Çizelge 8. Farklı yerleşim sıklıklarında yetiştirilen erkek ve dişi hindilerde tadım özellikleri.

\begin{tabular}{|c|c|c|c|c|c|c|}
\hline \multirow[b]{2}{*}{ Sex } & \multirow{2}{*}{$\begin{array}{l}\text { Stocking } \\
\text { Density } \\
\left(\mathrm{kg} \mathrm{m}^{-2}\right)\end{array}$} & \multicolumn{5}{|c|}{ Thigh Meat Organolepic Parameters } \\
\hline & & Color & Visual & Aroma & Crustiness & General \\
\hline \multirow{7}{*}{ Males } & 60 & $7.28 \pm 0.64$ & $7.28 \pm 0.52$ & $6.71 \pm 0.74$ & $6.42 \pm 0.78$ & $7.14 \pm 0.55$ \\
\hline & 50 & $5.85 \pm 0.63$ & $6.14 \pm 0.70$ & $5.71 \pm 0.83$ & $5.71 \pm 1.14$ & $6.71 \pm 0.52$ \\
\hline & 40 & $6.71 \pm 0.35$ & $6.57 \pm 0.64$ & $7.00 \pm 0.65$ & $6.42 \pm 0.61$ & $6.42 \pm 0.64$ \\
\hline & 30 & $6.14 \pm 0.67$ & $5.85 \pm 0.85$ & $7.42 \pm 0.42$ & $6.57 \pm 0.42$ & $7.28 \pm 0.42$ \\
\hline & Sx & 0.29 & 0.34 & 0.34 & 0.37 & 0.26 \\
\hline & $\mathrm{F}$ & 1.151 & 0.802 & 1.135 & 0.240 & 0.526 \\
\hline & $\mathrm{P}$ & $>0.05$ & $>0.05$ & $>0.05$ & $>0.05$ & $>0.05$ \\
\hline \multirow{7}{*}{ Females } & 60 & $6.80 \pm 0.96$ & $4.80 \pm 1.06 \mathrm{~b}$ & $5.80 \pm 0.73$ & $5.40 \pm 0.81$ & $5.40 \pm 0.67$ \\
\hline & 50 & $6.60 \pm 0.50$ & $5.20 \pm 0.66 a b$ & $7.20 \pm 0.37$ & $6.60 \pm 0.50$ & $6.40 \pm 0.60$ \\
\hline & 40 & $6.60 \pm 0.50$ & $6.60 \pm 0.40 a b$ & $6.60 \pm 0.67$ & $6.20 \pm 0.96$ & $6.80 \pm 0.58$ \\
\hline & 30 & $5.60 \pm 0.81$ & $7.20 \pm 0.66 \mathrm{a}$ & $6.80 \pm 0.58$ & $7.20 \pm 0.66$ & $7.20 \pm 0.37$ \\
\hline & Sx & 0.35 & 0.40 & 0.30 & 0.37 & 0.30 \\
\hline & $\mathrm{F}$ & 0.553 & 2367 & 0.937 & 0.991 & 1836 \\
\hline & $\mathrm{P}$ & $>0.05$ & $<0.05$ & $>0.05$ & $>0.05$ & $>0.05$ \\
\hline \multicolumn{7}{|c|}{ Breast Meat Organolepic Parameters } \\
\hline Sex & $\left(\mathrm{kg} \mathrm{m}^{-2}\right)$ & Color & Visual & Aroma & Crustiness & General \\
\hline \multirow{7}{*}{ Males } & 60 & $7.28 \pm 0.60$ & $7.28 \pm 0.42$ & $6.57 \pm 0.89$ & $6.85 \pm 0.59$ & $7.28 \pm 0.60$ \\
\hline & 50 & $6.42 \pm 0.36$ & $6.42 \pm 0.48$ & $7.00 \pm 0.53$ & $6.42 \pm 0.81$ & $6.57 \pm 0.61$ \\
\hline & 40 & $6.14 \pm 0.50$ & $6.28 \pm 0.86$ & $6.71 \pm 0.52$ & $5.57 \pm 0.81$ & $6.71 \pm 0.42$ \\
\hline & 30 & $6.14 \pm 0.82$ & $6.42 \pm 0.36$ & $6.85 \pm 0.85$ & $5.57 \pm 0.84$ & $7.14 \pm 0.26$ \\
\hline & Sx & 0.29 & 0.27 & 0.34 & 0.37 & 0.24 \\
\hline & $\mathrm{F}$ & 0.502 & 0.592 & 0.978 & 0.565 & 0.707 \\
\hline & $\mathrm{P}$ & $>0.05$ & $>0.05$ & $>0.05$ & $>0.05$ & $>0.05$ \\
\hline \multirow{7}{*}{ Females } & 60 & $6.40 \pm 0.92$ & $5.80 \pm 1.11$ & $5.20 \pm 0.73$ & $5.40 \pm 0.50$ & $5.40 \pm 0.67 b$ \\
\hline & 50 & $6.40 \pm 0.50$ & $6.40 \pm 0.50$ & $7.00 \pm 0.44$ & $6.60 \pm 0.24$ & $7.60 \pm 0.24 \mathrm{a}$ \\
\hline & 40 & $7.20 \pm 0.37$ & $7.20 \pm 0.58$ & $7.00 \pm 0.83$ & $6.00 \pm 0.63$ & $6.80 \pm 0.48 \mathrm{ab}$ \\
\hline & 30 & $7.60 \pm 0.74$ & $7.80 \pm 0.37$ & $6.60 \pm 0.74$ & $6.40 \pm 0.87$ & $7.20 \pm 0.73 \mathrm{a}$ \\
\hline & Sx & 0.33 & 0.36 & 0.36 & 0.29 & 0.32 \\
\hline & $\mathrm{F}$ & 0.791 & 1.562 & 1.460 & 0.757 & 2.821 \\
\hline & $\mathrm{P}$ & $>0.05$ & $>0.05$ & $>0.05$ & $>0.05$ & $<0.05$ \\
\hline
\end{tabular}

The statistically different data is shown with small characters and $P$ values are as given.

\section{CONCLUSION}

Stress and welfare are two of the main points of animal production and product quality. In Turkey birds are reared under stocking densities of $30-60 \mathrm{~kg} \mathrm{~m}^{-2}$. The experiment was designed to evaluate the current situation in the country on the term of some carcass parameters and meat quality to find out if there is a change in quality and taste of the meat of animals reared under different actual SDs.

In the experiment hot and cold carcass weights of birds, WHC, pH and color of breast and thigh meats of turkeys were investigated primarily to understand how SD affects meat quality.

In general, there has been found no significant change in carcass yield and investigated meat quality parameters but only some gustative parameters were found to be getting better by decreasing SD. This in fact can make a difference in public demand of this meat source and should be taken into attention.

Mainly it can be told that, the investigated SD levels do not have a significant effect on the investigated parameters, and can be applied by the industry by taking animal welfare issues and economy into consideration. Final conclusive decision to use the appropriate SD should be decided by taking these criteria of economy, welfare and performance together.

\section{ACKNOWLEDGMENT}

As a consultant during the entire Ph. D. period and during the research I give very special thanks to Prof. Dr. Rüveyde AKBAY. I wish to see many more scientists like her who will contribute to the promotion of our country and to the scientific community at such a high level. Also I would like to thank to Prof. Dr. Musa SARICA and 
Prof. Dr. Hasan ÖNDER for their great support during statistical analyses and interpretation of the data. Also special thanks to Bolca Hindi owner Şerafettin ERBAYRAM and turkey grower Avni ERATEŞ may Allah (CC) has mercy on his soul.

\section{REFERENCES}

Azzam, M. M. M., \& Gogary, M. R. E. I. (2015). Effects of dietary threonine levels and stocking density on the performance, metabolic status and immunity of broiler chickens. Asian Journal of Animal and Veterinary Advances, 10(5), 215-225.

Barbut, S. (1998). Estimating the magnitude of the PSE problem in poultry. Journal of Muscle Foods, 9, 35-49.

Doğrul, M., Demir, H., \& Ekiz, B. (2005). Farklı yerleşim sıklığında yetiştirilen erkek hindilerin besi performansı ve karkas özellikleri. Istanbul Üniversitesi Veteriner Fakültesi Dergisi, 31(2), 113-131.

Düzgüneş, O., Kesic, T., Kavuncu, O., \& Gürbüz, F. (1987). Araştırma ve Deneme Metotları. Ankara Üniversitesi Ziraat Fakültesi Yayınları No:1021, 381p. Ankara.

Eratalar S. A. \& Bulut O. (2007). Türkiye'de hindi yetiştiriciligi. Veteriner Tavukçuluk Dernegi Dergisi, 5(3), 11-19.

Ergün, A., Tuncer, Ş. D., Çolpan, I., Yalçın, S., Yıldız, G., Küçükersan, M. K., Küçükersan, S., \& Şehu, A. (2001). Hayvan Besleme ve Beslenme Hastalıları. Medipres, $\mathrm{P}(\mathrm{XVI}+455)$, Ankara.

Ertugrul, M., Akman, N., Aşkın, Y., Cengiz, F., Ertugrul, M., Fıratlı, Ç., Türkoglu, M., \& Yener, M. (1997). Hayvan Yetiştirme (Yetiştiricilik). Baran Ofset, Ankara.

FAO. (2015). Livestock production. http://www.fao.org/docrep/005/y4252e/y4252e07.htm. Access: 07 November 2016.

Farmer, L. J., Perry, G. C., Lewis, P. D., Nute, G. R., Piggott, J. R., \& Patterson, R. L. S. (1997). Responses of two genotypes of chicken to the diets and stocking densities typical of UK and "Label Rouge" Production Systems: II. Sensory Attributes. Meat Science, 47, 7-93.

Gatchalian, M. M. (1999). Quality assesment through statistically based sensory evaluation methods. The TQM Magazine, 11(6), 389-396.

Houshmand, M., Azhar, K., Zulkifli, I., Bejo, M. H., \& Kamyab, A. (2012). Effects of prebiotic, protein level and stocking density on performance, immunity and stress indicators of broilers. Poultry Science, 91, 393-401.

MINITAB 14. (2004). Statistical Software. Minitab Inc. Quality Plaza, 1829 Pine Hall Road State College, PA 16801-3008, USA.

Mirabito, L., Barthelot, A., Baron, F., Bouvarel, L., Aubert, C., Bocquier, C., Dalibard, F., Sante, V., \& Pottier, G. (2002). Influence of reducing the stocking density of the performance, behavior and physical integrity of meat turkeys. 11. European Poultry Conference. Berlin.

Molette, C., Remignon, H., \& Babile, R. (2005). Modification of glicolyzing enzymes lowers meat quality of turkey. Poultry Science, 84, 119-127.

Noll, S. L., Halawani, M. E. E., Waibel, P. E., Redig, P., \& Janni, K. (1991). Effect of diet and population density on male turkeys under various environmental conditions. 1. Turkey growth and health performance. Poultry Science, 70, 923-934.

Peryam, D. R. \& Pilgrim, F. J. (1957). Hedonic scale method for measuring food preferences. Food Technology, 11, 9-14.

Poste, L. M. (1990). A sensory perspective of effect of feeds on flavour in meats: Poultry meats. Journal of Animal Science, 68 , 4414-4420.

Proudfoot, F. G., \& Hulan, H. W. (1985). Effects of stocking density on the incidence of scabby hip syndrome among broiler chickens. Poultry Science, 10, 2001-2003.

Qaid, M., Albatshan, H., Shafey, T., Hussein, E., \& Abudabos, A. M. (2016). Effect of stocking density on the performance and immunity of 1-14-d - old broiler chicks. Brasilian Journal of Poultry Science, 18(4), 683-691.

Reilly, T. I., \& York, R. K. (2001). Guidance on Sensory Testing and Monitoring of Seafood for Presence of Petroleum Taint Following an Oil Spill. NDAA Technical Memorandum NOS OR\&R, No:9. Washington, USA.

Riegel, J., Maak, S., Behr, K. P., \& Wicke, M. (2004). Investigations on meat quality of the pectoralis superficialis in turkey depending on line and age. XXII. World's Poultry Congress, İstanbul.

Santos, A. L., Sakomura, N. K., Freitas, E. R., Barbosa, N. A. A., Mendonça, M. O., \& Carrilho, E. N. V. M. (2004). Carcass yield and meat quality of three strains of broiler chicken. XXII. World's Poultry Congress, İstanbul.

Sheskin, D. J. (2000). Handbook of parametric and non-parametric statistical procedures (second edition). Western Connecticut University. Chapman \& Hull, 1061p, USA. 
Thomas, D. G., Ravindran, V., Thomas, D. V., Camden, B. J., Cottam, Y. H., Morel, P. C. H., \& Cook, C. J. (2004). The effect of stocking density on broiler performance. XXII. World's Poultry Congress, İstanbul.

TUIK. (2016). Hayvansal üretim istatistikleri. http://www.tuik.gov.tr/PreHaberBultenleri.do?id=21871. Access: 07 September 2016.

Turhan, K. (1992). Potasyum sorbat ve laktik asitin vakum paketlenmis tavuk etlerinin raf ömrüne etkisi. Yüksek Lisans Tezi, Ankara Üniversitesi, Fen Bilimleri Enstitüsü, Ankara.

$\mathrm{Xu}, \mathrm{L}$. (1999). The removal of phenolic compounds for the production of high quality canola protein isolates. Graduate Department of Chemical Engineering and Applied Chemistry, University of Toronto. Canada. 